\title{
Multidrug resistant and ESBL-producing Salmonella spp. isolated from poultry
}

\section{Salmonella spp. produtora de ESBL e multirresistente a drogas isolada de frangos}

\author{
Marielen de Souza ${ }^{1}$; Daniela Aguiar Penha Brito ${ }^{2}$; Maísa Fabiana Menck-Costa ${ }^{1}$; \\ Alexandre $\mathrm{Oba}^{3}$; Renata Katsuko Takayama Kobayashi' ${ }^{4}$ Larissa Justino'; \\ Ana Angelita Sampaio Baptista ${ }^{5 *}$
}

\begin{abstract}
Salmonella spp. is one of the main agents responsible for foodborne infection in humans, and products of poultry origin are the most common infection sources. Studies have shown the occurrence of antimicrobials resistant Salmonella spp. in animal products. The Extended Spectrum $\beta$-Lactamase (ESBL) are enzymes that confer to bacteria the ability to hydrolyze cephalosporin with an oximino side chain and monobactams. This study aimed to investigate antimicrobial resistance profile, identify phenotypes and genotypes for multiple drug resistance (MDR) and that produce ESBL from isolates of Salmonella spp. in the broiler production chain. We used samples of Salmonella spp. $(\mathrm{n}=11)$ isolates from poultry, poultry products and poultry-source environment from the state of Maranhão - Brazil. The isolates of Salmonella spp. assessed showed genotypical and phenotypical characteristics of MDR. The results show that $72.72 \%(08 / 11)$ of the strains presented the phenotypic profile for ESBL production. The isolates showed positivity to at least $13.64 \%(03 / 22)$ of the genes studied and the highest frequencies were observed in genes $\operatorname{sul}_{1}(73 \%), d f r_{\mathrm{A} 12}(55 \%)$, bla $_{\mathrm{CTX}-\mathrm{M}}(55 \%)$, tet $_{\mathrm{A}}$, tet $_{\mathrm{B}}$ and $t e t_{\mathrm{C}}$, with $45 \%$. In conclusion, the strains of Salmonella spp. isolates present genotypic and phenotypic characteristics for MDR and ESBL production, demonstrating the dissemination risk of these microorganisms through the food chain.
\end{abstract}

Key words: Zoonosis. Broiler Chicken. Antimicrobials. Resistance Genes.

\section{Resumo}

Salmonella spp. é um dos principais agentes responsáveis por infecção de origem alimentar em humanos, sendo os produtos de origem avícola apontados como as fontes de infecção mais frequentes. Estudos demonstraram a ocorrência de Salmonella spp. resistente a antimicrobianos em produtos de origem animal. As $\beta$-lactamases de espectro extendido (ESBL) são enzimas que conferem às bactérias a capacidade de hidrolisar cefalosporinas com uma cadeia lateral oximino e monobactâmicos. Este estudo objetivou investigar o perfil de resistência a antimicrobianos, identificar fenótipos e genótipos de multirresistência a drogas (MDR), e produção de ESBL em isolados de Salmonella spp. provenientes da

\footnotetext{
${ }^{1}$ Médicas Veterinárias, Discentes de Pós-Graduação, Universidade Estadual de Londrina, UEL, Londrina, PR, Brasil. E-mail: marielen_desouza@hotmail.com; maisafabi@hotmail.com; larissajustino.veterinaria@gmail.com

2 Médica Veterinária, Prof ${ }^{a}$ Dr $^{\mathrm{a}}$, Instituto Federal do Maranhão, IFMA, São Luís, MA, Brasil. E-mail: danielabrito@ifma.edu.br

3 Zootecnista, Prof. Dr., Departamento de Zootecnia, UEL, Londrina, PR, Brasil. E-mail: oba@uel.br

4 Farmacêutica Bioquímica, Prof ${ }^{a}, D^{\mathrm{a}}$, Departamento de Microbiologia, UEL, Londrina, PR, Brasil. E-mail: kobayashirkt@uel.br

${ }_{5}$ Médica Veterinária, Prof ${ }^{\mathrm{a}} \mathrm{Dr}^{\mathrm{a}}$, Departamento de Medicina Veterinária Preventiva, UEL, Londrina, PR, Brasil. E-mail: anaangelita@uel.br

* Author for correspondence
} 
cadeia produtiva de frangos de corte. Foram utilizadas amostras de Salmonella $\mathrm{spp}$. (n=11) isoladas de aves, produtos e ambiente de origem avícola do estado do Maranhão - Brasil. Os isolados de Salmonella spp. avaliados apresentaram resistência múltipla a drogas tanto genotípica quanto fenotipicamente. Os resultados mostram que 72,72\% (08/11) das cepas apresentaram perfil fenotípico de produção de ESBL. Os isolados apresentaram positividade a pelo menos $13,64 \%(03 / 22)$ dos genes pesquisados, sendo as maiores frequências observadas nos genes $s u l_{1}(73 \%), d f r_{\mathrm{Al} 2}(55 \%)$, bla $_{\mathrm{CTX}-\mathrm{M}}(55 \%)$, tet $_{\mathrm{A}}$, tet $_{\mathrm{B}}$ e $t e t_{\mathrm{C}}$, com $45 \%$. Conclui-se que as cepas de Salmonella spp. isoladas apresentam características genotípicas e fenotípicas de multirresistência a drogas e produção de ESBL, demonstrando o risco de disseminação destes microrganismos ao longo da cadeia alimentar.

Palavras-chave: Zoonose. Frango de Corte. Antimicrobianos. Genes de Resistência.

\section{Introduction}

Salmonella spp. is one of the main agents responsible for Foodborne Diseases (FBD) in humans, both in developing and developed countries (ABD-ELGHANY et al., 2015). In the United States alone, the agent accounts for 896 outbreaks, 23.662 illnesses, 3.168 hospitalization and 29 deaths by FBD confirmed cases, between 2009-2015 (DEWEY-MATTIA et al., 2018).

Products of poultry origin are accounted as the most common sources of infection (MELENDEZ et al., 2010). Studies have shown the occurrence of Salmonella spp. resistant to antimicrobials in animal products and consequently the potential for transmission of the agent along the food chain (WANG et al., 2013; ZIECH et al., 2016). Samples of multiresistant Salmonella spp. are considered a public health issue, as they limit therapeutic options for salmonellosis treatment in humans (ZISHIRI et al., 2016).

Extended Spectrum $\beta$-Lactamase (ESBL) are enzymes that confer to the bacteria the ability to hydrolyze cephalosporin with an oximino side chain (ceftriaxone, ceftazidime, cefotaxime) and monobactams (aztreonan). This complex group of enzymes is transported by plasmids of rapid development, increasing challenges in the treatment of hospitalized patients, from cases of urinary tract infections to sepsis (RAWAT; NAIR, 2010).

Currently, more than 400 ESBLs are described. The CTX-M group encompasses at least 168 variations (LAHEY CLINIC, 2017). Bacteria can acquire resistance to antibiotics mainly by chromosomal mutation and acquisition of mobile genetic elements such as plasmids by horizontal gene transfer (MILLAN, 2018). Plasmids are extrachromosomal DNA molecules that replicate independently of the chromosome and can carry resistance to other drugs, such as aminoglycosides, trimethoprim, sulfonamides, tetracycline and chloramphenicol (CARATTOLI, 2013; PITOUT et al., 2005).

This study aimed to determine the antimicrobial resistance profile, identify phenotypic and genotypic characteristics for multiple drug resistance (MDR) and for ESBL production in isolates of Salmonella spp. from different sources of the broiler production chain.

\section{Material and Methods}

\section{Ethical aspects}

The present work was carried out after approval by the Ethics Committee on the Use of Animals (CEUA - in Portuguese) - UEL, registered under Protocol No. 178/2014.

\section{Bacterial isolates}

We used samples of Salmonella spp. $(n=11)$ isolates from poultry, poultry products and poultrysource environment from the state of Maranhão, 
Brazil, five isolates of carcasses from artisanal slaughterhouses, four from the environment (drag swab and boot swab, from poultry shed) and two from broiler chickens (cloaca swabs). The samples were processed between 2013 to 2014, at the Microbiology Laboratory from the Instituto Federal de Educação do Maranhão (IFMA), according to normative instruction No. 8, MAPA (MAPA, 1995), and serotyping by Instituto Oswaldo Cruz (FIOCRUZ), Rio de Janeiro, Brazil. The serovars found are described in Table 1.

Table 1. Salmonella spp. strains isolated in this study.

\begin{tabular}{ccc}
\hline Serovar & N & Source \\
\hline S. Albany & 01 & Carcasses \\
$S$. Schwarzengrund & 09 & Environment (03); broiler chickens (02); Carcasses (04) \\
S. Typhimurium & 01 & Environment \\
\hline Total & $\mathbf{1 1}$ & \\
\hline
\end{tabular}

\section{Antimicrobial susceptibility test}

The Disk Diffusion test (BAUER et al., 1966) was used to determine the antimicrobial susceptibility profile, according to protocol of Clinical and Laboratory Standards Institute (CLSI, 2017). Strains of Escherichia coli ATCC 25922 and
Salmonella Enteritidis ATCC 13076 were used as control. The antimicrobials tested are described in Table 2. Isolates with resistance to three or more classes of antimicrobials simultaneously were considered a phenotype with multiple drug resistance (MDR) (MAGIORAKOS et al., 2012). 
Table 2. Antimicrobials tested and therapeutic application in human and veterinary medicine.

\begin{tabular}{|c|c|c|c|c|c|}
\hline & \multirow[b]{2}{*}{ Antimicrobial class } & \multirow[b]{2}{*}{ Antimicrobial } & \multicolumn{3}{|c|}{ Therapeutic application } \\
\hline & & & $\begin{array}{c}\text { Only } \\
\text { human } \\
\text { medicine }\end{array}$ & $\begin{array}{c}\text { Only } \\
\text { veterinary } \\
\text { medicine }\end{array}$ & $\begin{array}{c}\text { Human and } \\
\text { veterinary } \\
\text { medicine }\end{array}$ \\
\hline \multirow{23}{*}{ 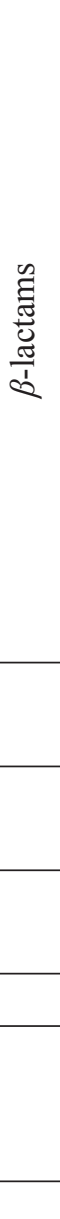 } & Carbapenens & imipenem - $10 \mu \mathrm{g}$ & & & $\mathrm{X}$ \\
\hline & cephalosporin of first generation & 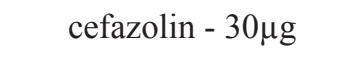 & & & $\mathrm{X}$ \\
\hline & cephalosporin of second generation & cefoxitin $30 \mu \mathrm{g}$ & & & $\mathrm{X}$ \\
\hline & & cefotaxime $30 \mu \mathrm{g}$ & & & $\mathrm{X}$ \\
\hline & & ceftazidime $30 \mu \mathrm{g}$ & & & $\mathrm{X}$ \\
\hline & cepnaiosporm or tnira generation & ceftiofur $30 \mu \mathrm{g}$ & & $\mathrm{X}$ & \\
\hline & & ceftriaxone $30 \mu \mathrm{g}$ & & & $\mathrm{X}$ \\
\hline & cephalosporin of fourth generation & cefepime $30 \mu \mathrm{g}$ & & & $\mathrm{X}$ \\
\hline & Monobactams & aztreonam - $30 \mu \mathrm{g}$ & & & $\mathrm{X}$ \\
\hline & \multirow{3}{*}{ Penicillin } & amoxicillin - $10 \mu \mathrm{g}$ & & & $\mathrm{X}$ \\
\hline & & $\begin{array}{c}\text { amoxicillin } 20 \mu \mathrm{g} \\
+ \text { acid clavulanic } 10 \mu \mathrm{g}\end{array}$ & & & $\mathrm{X}$ \\
\hline & & ampicillin - $10 \mu \mathrm{g}$ & & & $\mathrm{X}$ \\
\hline & \multirow{2}{*}{ Aminoglycosides } & gentamicin - $10 \mu \mathrm{g}$ & & & $\mathrm{X}$ \\
\hline & & streptomycin - $300 \mu \mathrm{g}$ & & & $\mathrm{X}$ \\
\hline & \multirow{2}{*}{ Fenicoles } & chloramphenicol - 30 $\mu \mathrm{g}$ & $\mathrm{X}$ & & \\
\hline & & florfenicol - $30 \mu \mathrm{g}$ & & & $\mathrm{X}$ \\
\hline & \multirow{2}{*}{ inhibitors of folates } & sulfonamide - $300 \mu \mathrm{g}$ & & & $\mathrm{X}$ \\
\hline & & trimethoprim - $5 \mu \mathrm{g}$ & & & $\mathrm{X}$ \\
\hline & Nitrofurans & nitrofurantoin - $300 \mu \mathrm{g}$ & $\mathrm{X}$ & & \\
\hline & \multirow{3}{*}{ Quinolones } & acid nalidixic - $30 \mu \mathrm{g}$ & & & $\mathrm{X}$ \\
\hline & & ciprofloxacin - $5 \mu \mathrm{g}$ & & & $\mathrm{X}$ \\
\hline & & norfloxacin - $10 \mu \mathrm{g}$ & & & $\mathrm{X}$ \\
\hline & Tetracycline & tetracycline $-30 \mu \mathrm{g}$ & & & $\mathrm{X}$ \\
\hline
\end{tabular}

Brazil's legislation - prohibit chloramphenicol and nitrofurans as growth promoters and therapeutic use (MAPA, 2003); tetracyclines, penicillins, cephalosporins, quinolones and sulfonamides are prohibit to be used as growth promoters, only the therapeutic use is available (MAPA, 2009).

Genotypic profile of antimicrobial resitance and ESBL production

We determined resistance to beta-lactams $\left(\left(b l a_{\text {СTХ-М }}, b l a_{\text {СTХ-M1}}, b l a_{\text {СТХ-M2}}, b l a_{\text {СТХ-M15 }}, b l a_{\text {ОХА }}\right.\right.$, $b l a_{\mathrm{SH}}, b l a_{\mathrm{TEM}}-$ ESBL production) and $b l a_{\mathrm{CMY}-2}$ - production of AmpC), inhibitors of folates (trimethoprim $d f r_{\mathrm{A} 1}, d f r_{\mathrm{A} 7}, d f r_{\mathrm{A} 12}, d f r_{\mathrm{A} 14}, d r f_{\mathrm{B}}$; and to sulfonamides $s u l_{1}, s u l_{2}, s u l_{3}$ ) and to tetracycline $\left(\right.$ tet $_{\mathrm{A}}$, tet $_{\mathrm{B}}$, tet $_{\mathrm{C}}$, tet $_{\mathrm{D}}$, tet $_{\mathrm{E}}$ and tet $\left._{\mathrm{G}}\right)$. The reactions were prepared as follows: $80 \mathrm{ng}$ of DNA template,
Buffer 1x (Invitrogen), $50 \mathrm{mM}$ of $\mathrm{MgCl} 2,2.5 \mathrm{mM}$ of each dNTP, $1 \mathrm{uL}$ of each primer $(10 \mu \mathrm{M}), 1 \mathrm{uL}$ of taq DNA Polymerase (5 U/ $\mu \mathrm{L})$ (Invitrogen). The PCR Protocol consisted of an initial denaturation cycle at $94^{\circ} \mathrm{C}$ for $2 \mathrm{~min}$, followed by 30 cycles of denaturation at $94^{\circ} \mathrm{C}$ for $1 \mathrm{~min}$, hybridization for $1 \mathrm{~min}$ and extension at $72^{\circ} \mathrm{C}$ for $1 \mathrm{~min}$, and final extension at $72^{\circ} \mathrm{C}$ for $10 \mathrm{~min}$. Table 3 shows the sequence of every gene primer tested. 
Table 3. Primers used in this study.

\begin{tabular}{|c|c|c|c|c|}
\hline $\begin{array}{l}\text { Antimicrobial } \\
\text { Class }\end{array}$ & Gene & Sequence (5'-3') & $\begin{array}{l}\text { PCR product } \\
\text { size (bp) }\end{array}$ & Reference \\
\hline \multirow{8}{*}{ 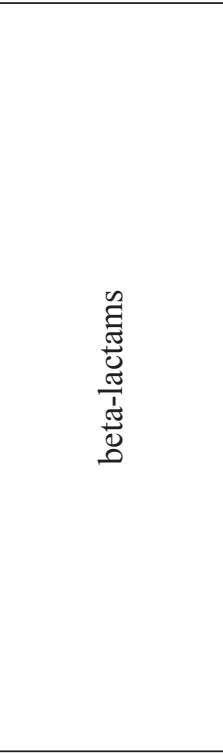 } & $b l a_{\mathrm{CMY}-2} * *$ & $\begin{array}{l}\text { F: TGGCCGAACTGACAGGCAAA } \\
\text { R: TTTCTCCTGAACGTGGCTGGC }\end{array}$ & 870 & $\begin{array}{l}\text { Chen et al. } \\
\text { (2004) }\end{array}$ \\
\hline & $b l a_{\mathrm{CTX}-\mathrm{M}} *$ & $\begin{array}{l}\text { F: TTTGCGATGTGCAGTACCAGTAA } \\
\text { R: CGATATCGTTGGTGGTGCCATA }\end{array}$ & 544 & $\begin{array}{l}\text { Silva et al. } \\
\quad(2011)\end{array}$ \\
\hline & $b l a_{\mathrm{CTX-M1}} *$ & $\begin{array}{l}\text { F: GACGATGTCACTGGCTGAGC } \\
\text { R: AGCCGCCGACGCTAATACA }\end{array}$ & 499 & $\begin{array}{l}\text { Silva et al. } \\
\quad(2011)\end{array}$ \\
\hline & $b l a_{\text {СТХ-M2 }} *$ & $\begin{array}{l}\text { F: GCGACCTGGTTAACTACAATC } \\
\text { R: CGGTAGTATTGCCCTTAAGCC }\end{array}$ & 351 & $\begin{array}{l}\text { Silva et al. } \\
\quad(2011)\end{array}$ \\
\hline & $b l a_{\mathrm{CTX}-\mathrm{M} 15} *$ & $\begin{array}{l}\text { F: CACACGTGGAATTTAGGGACT } \\
\text { R: GCCGTCTAAGGCGATAAACA }\end{array}$ & 564 & $\begin{array}{l}\text { Silva et al. } \\
\text { (2011) }\end{array}$ \\
\hline & $b l a_{\mathrm{OXA}} *$ & $\begin{array}{l}\text { F: ACCAGATTCAACTTTCAA } \\
\text { R: TCTTGGCTTTTATGCTTG }\end{array}$ & 598 & $\begin{array}{l}\text { Gallardo et al. } \\
\text { (1999) }\end{array}$ \\
\hline & $b l a_{\mathrm{SHV}}{ }^{*}$ & $\begin{array}{l}\text { F: ATGCGTTATATTCGCCTGTG } \\
\text { R: GTTAGCGTTGCCAGTGCTCG }\end{array}$ & 573 & $\begin{array}{l}\text { Silva et al. } \\
\text { (2011) }\end{array}$ \\
\hline & $b l a_{\mathrm{TEM}} *$ & $\begin{array}{l}\text { F: ATGAGTATTCAACATTTCCGTG } \\
\text { R: TTACCAATGCTTAATCAGTGAG }\end{array}$ & 861 & $\begin{array}{l}\text { Silva et al. } \\
(2011)\end{array}$ \\
\hline \multirow{8}{*}{ 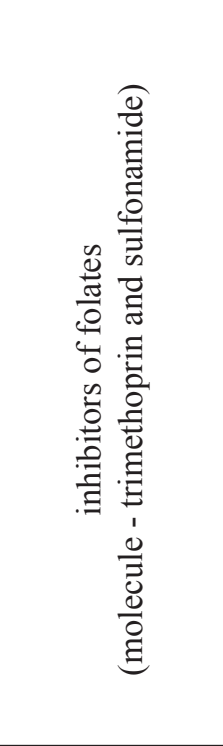 } & $d r f_{\mathrm{A} 1}$ & $\begin{array}{l}\text { F:GTGAAACTATCACTAATGG } \\
\text { R: TTAACCCTTTTGCCAGATTT }\end{array}$ & 474 & $\begin{array}{l}\text { Navia et al. } \\
\quad(2003)\end{array}$ \\
\hline & $d f r_{\mathrm{A} 7}$ & $\begin{array}{l}\text { F: TTGAAAATTTCATTGATTG } \\
\text { R: TTAGCCTTTTTTCCAAATCT }\end{array}$ & 474 & $\begin{array}{l}\text { Navia et al. } \\
\quad(2003)\end{array}$ \\
\hline & $d f r_{\mathrm{A} 12}$ & $\begin{array}{l}\text { F: GGTGSGCAGAAGATTTTTCGC } \\
\text { R: TGGGAAGAAGGCGTCACCCTC }\end{array}$ & 319 & $\begin{array}{l}\text { Navia et al. } \\
\quad(2003)\end{array}$ \\
\hline & $d f r_{\mathrm{A} 14}$ & $\begin{array}{l}\text { F:GAGCAGCTICTITTIAAAGC } \\
\text { R:TTAGCCCTTTIICCAATTTT }\end{array}$ & 393 & $\begin{array}{l}\text { Navia et al. } \\
\quad(2003)\end{array}$ \\
\hline & $d f r_{\mathrm{B}}$ & $\begin{array}{l}\text { F: GATCACGTGCGCAAGAAATC } \\
\text { R:AAGCGCAGCCACAGGATAAAT }\end{array}$ & 141 & $\begin{array}{l}\text { Navia et al. } \\
\quad(2003)\end{array}$ \\
\hline & $S u l_{1}$ & $\begin{array}{l}\text { F: TTTCCTGACCCTGCGCTCTAT } \\
\text { R: GTGCGGACGTAGTCAGCGCCA }\end{array}$ & 425 & $\begin{array}{l}\text { Ma et al. } \\
\text { (2007) }\end{array}$ \\
\hline & $\mathrm{Sul}_{2}$ & $\begin{array}{l}\text { F: CCTGTTTCGTCCGACACAGA } \\
\text { R: GAAGCGCAGCCGCAATTCAT }\end{array}$ & 435 & $\begin{array}{l}\text { Ma et al. } \\
(2007)\end{array}$ \\
\hline & $\mathrm{Sul}_{3}$ & $\begin{array}{l}\text { F: ATGAGCAAGATTTTTGGAATCGTAA } \\
\text { R: CTAACCTAGGGCTTTGGTATTT }\end{array}$ & 792 & $\begin{array}{l}\text { Ma et al. } \\
(2007)\end{array}$ \\
\hline \multirow{6}{*}{ 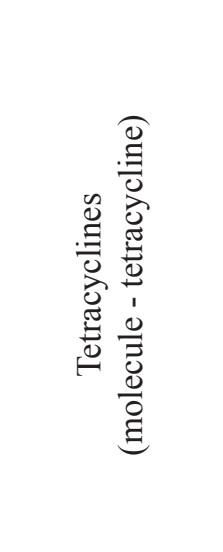 } & $t e t_{\mathrm{A}}$ & $\begin{array}{l}\text { F: TTGGCATTCTGCATTCACTC } \\
\text { R: GTATAGCTTGCCGGAAGTCG }\end{array}$ & 494 & $\begin{array}{l}\text { Ma et al. } \\
(2007)\end{array}$ \\
\hline & $t e t_{\mathrm{B}}$ & $\begin{array}{l}\text { F: CAGTGCTGTTGTGTCATTAA } \\
\text { R: GCTTGGAATACTGAGTGTAA }\end{array}$ & 571 & $\begin{array}{l}\text { Ma et al. } \\
(2007)\end{array}$ \\
\hline & tet $_{\mathrm{C}}$ & $\begin{array}{l}\text { F: CTTGAGAGCCTTCAACCCAG } \\
\text { R: ATGGTCGTCATCTACCTGCC }\end{array}$ & 418 & $\begin{array}{l}\text { Ma et al. } \\
(2007)\end{array}$ \\
\hline & tet $_{\mathrm{D}}$ & $\begin{array}{l}\text { F: GCTCGGTGGTATCTCTGCTC } \\
\text { R: AGCAACAGAATCGGGAACAC }\end{array}$ & 546 & $\begin{array}{l}\text { Ma et al. } \\
(2007)\end{array}$ \\
\hline & $t e t_{\mathrm{E}}$ & $\begin{array}{l}\text { F: TATTAACGGGCTGGCATTTC } \\
\text { R: AGCTGTCAGGTGGGTCAAAC }\end{array}$ & 544 & $\begin{array}{l}\text { Ma et al. } \\
(2007)\end{array}$ \\
\hline & $t e t_{\mathrm{G}}$ & $\begin{array}{l}\text { F: GCTCGGTGGTATCTCTGCTC } \\
\text { R: CAAAGCCCCTTGCTTGTTAC }\end{array}$ & 550 & $\begin{array}{l}\text { Ma et al. } \\
(2007)\end{array}$ \\
\hline
\end{tabular}

$(* *)$ - gene that also indicate Amp-C production. $(*)$ - gene that also indicate ESBL production. F: forward, R: reverse 


\section{Phenotypic profile for ESBL production}

Production of Extended Spectrum $\beta$-Lactamase (ESBL) was determined by the disk approximation test, according to Clinical and Laboratory Standards Institute (CLSI, 2017). The antimicrobial discs used were: amoxicillin + clavulanic acid (AMC $30 \mu \mathrm{g}$ ), aztreonam (ATM $30 \mu \mathrm{g}$ ), ceftazidime (CAZ $30 \mu \mathrm{g}$ ), ceftriaxone (CRO $30 \mu \mathrm{g}$ ), cefotaxime (CTX 30 $\mu \mathrm{g})$. The AMC disk was applied at the plate center containing agar Mueller Hinton ( $\mathrm{MH}$ ) and the others at $20 \mathrm{~mm}$ from the edge of the central disk. The sample was considered positive when there was an increase in inhibition zone, with deformation in a halo of antibiotics prepared around the central disk of AMC. We also perform the phenotypic profile for ESBL production because the fact that bacteria has an ESBL gene does not means that it is able to express the resistance.

\section{Results}

The 11 isolates of Salmonella spp. assessed showed phenotypical multiple resistance to drugs, and all of them showed genotypical resistance to at list two classes of antimicrobials (Table 4). A sample of $S$. Schwarzengrund (isolate No. 05, no-ESBL producing), from the environment, presented the lowest MDR to 5 from 13 (38.46\%) classes of antimicrobials tested. The highest MDR was observed in two samples of the same serovar (isolates No. 07 and 08, both ESBL-producing), however, from broiler chickens with resistance to $09 / 13(69.23 \%)$ of the antimicrobials classes tested.
Regarding the phenotypic profile for ESBL production, only $27.27 \%(03 / 11)$ of the isolates were negative, all belonging to the serovar $S$. Schwarzengrund, two samples were isolates from the carcass and one from the environment, $72.73 \%(08 / 11)$ of the isolates were positive for ESBL production. Regarding ESBL isolates origin $37.5 \%(03 / 08)$ were from the carcass, $25 \%(02 / 08)$ from broiler chickens and $37.5 \%(03 / 08)$ from the environment. AMO, AMP, CFZ, SUL, TET, and TRI were the antimicrobials with the largest resistance percentages (Figure 1).

The isolates showed positivity to at least $13.64 \%$ $(03 / 22)$ of the genes studied. A sample of serovar $S$. Schwarzengrund from the carcass presented the highest percentage of positivity, $31.82 \%(07 / 22)$. The genes mostly found confer resistance the sulfonamides $\left(s_{1} l_{1}\right)$ 72,73\% (08/11), trimethoprim $\left(d f r_{\mathrm{A} 12}\right) 54,54 \%(06 / 11), \beta$-lactam $\left(b l a_{\text {СТX M}}\right) 54,54 \%$ $(06 / 11)$ and tetracycline $\left(\right.$ tet $_{\mathrm{A}}$, tet $_{\mathrm{B}}$ and tet $\left._{\mathrm{C}}\right) 45,45 \%$ $(05 / 11)$, resembling the phenotypic profile (Figure 2).

The comparison of genotypic with phenotypic profiles of the isolates showed that $63.64 \%(07 / 11)$ presented genes for ESBL production of which $28.57 \%$ (02/07, isolates No. 06 and 09) had the genes; however, they were not ESBL producers in the phenotypic evaluation. Another $27.27 \%(03 / 11$, isolates No. 02, 04 and 11) presented phenotypic profile for ESBL production, despite the absence of genes that confer this capacity assessed in this study. 


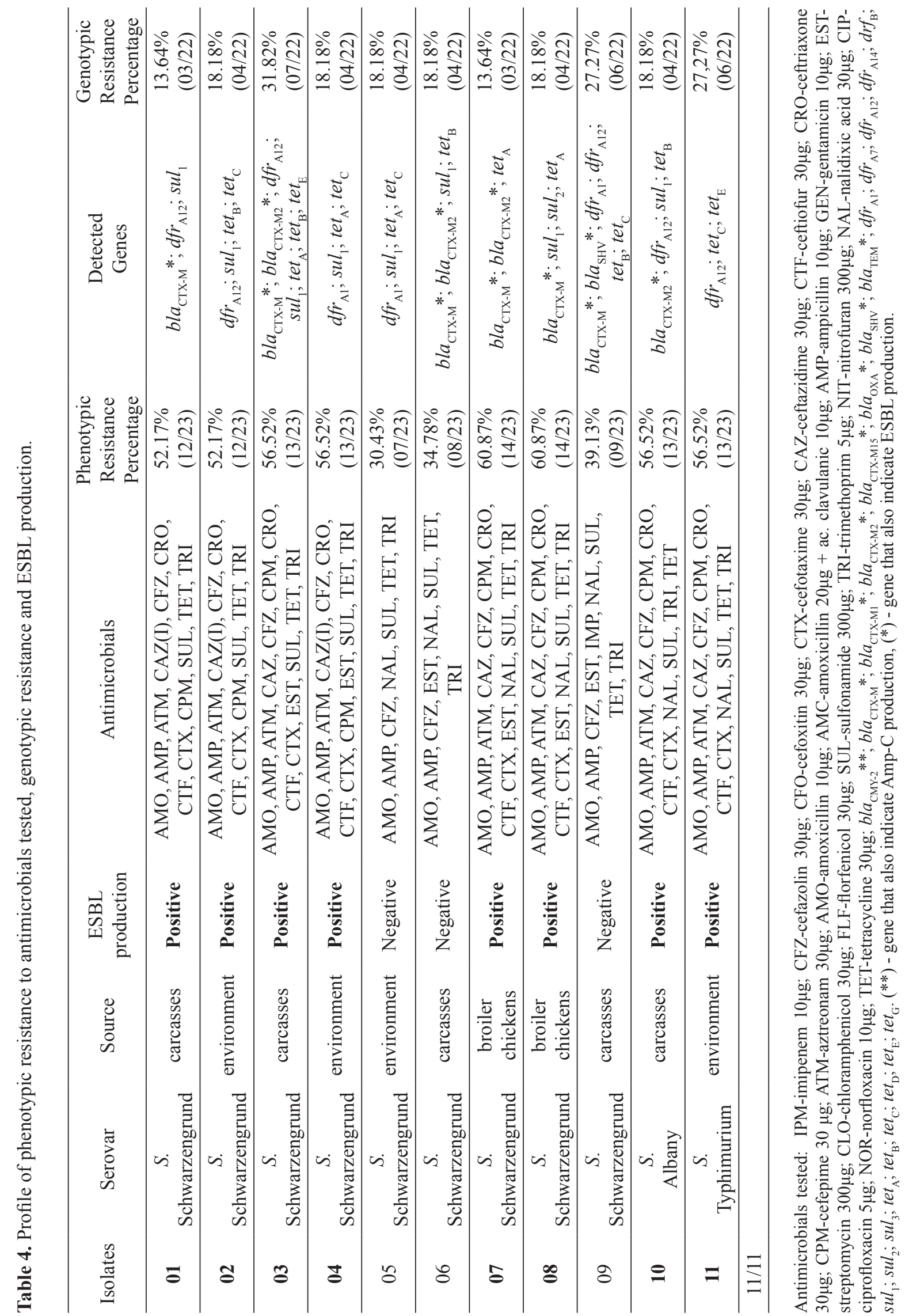


Figure 1. Antimicrobial resistance of Salmonella spp. isolates.

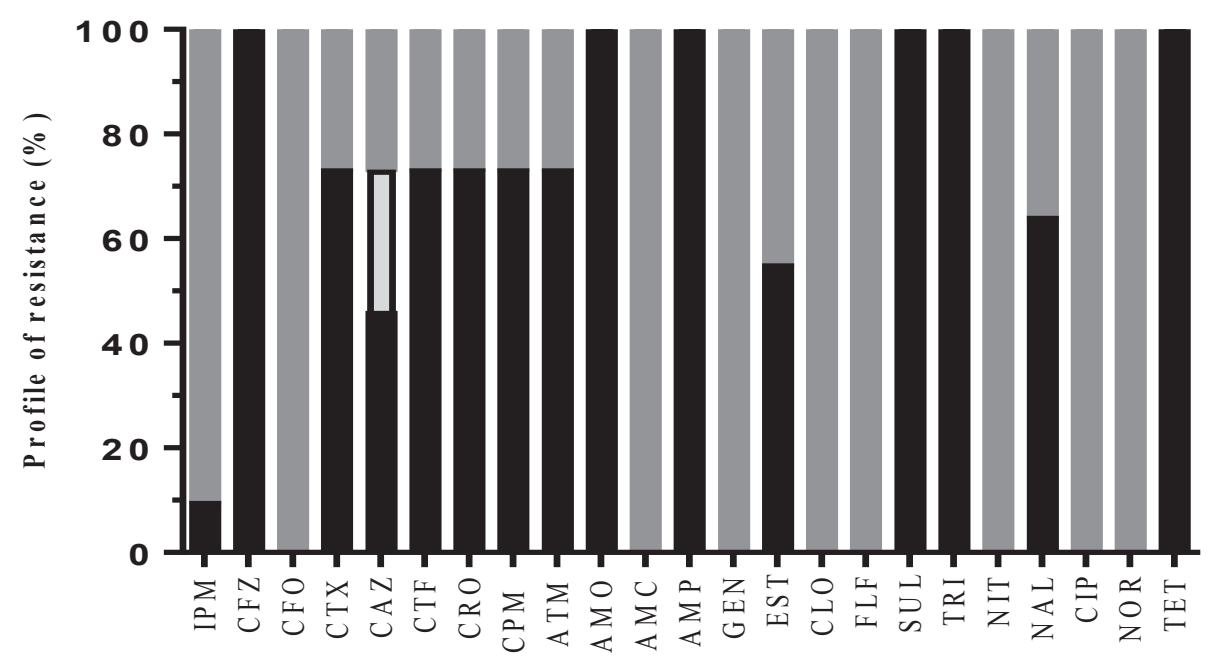

Antim icrobials tested

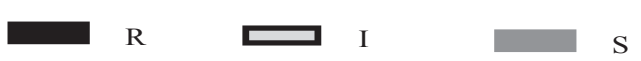

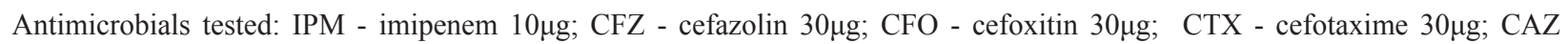

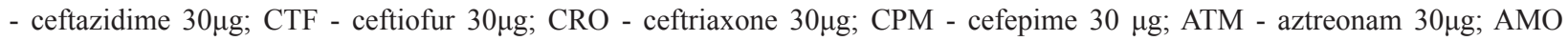

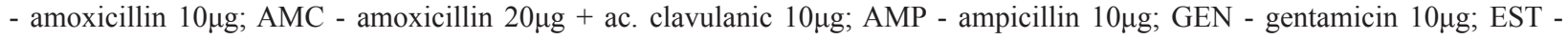

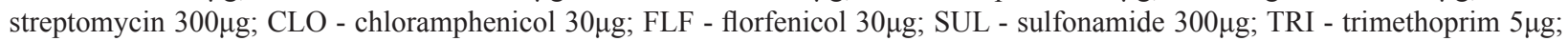

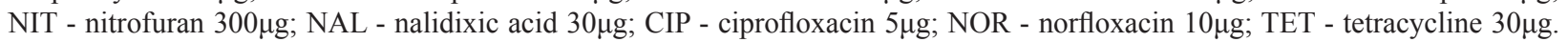
R - Resistant; I - Intermediate; S - Susceptible.

Figure 2. Genotypic resistance (\%) of Salmonella spp. isolates.

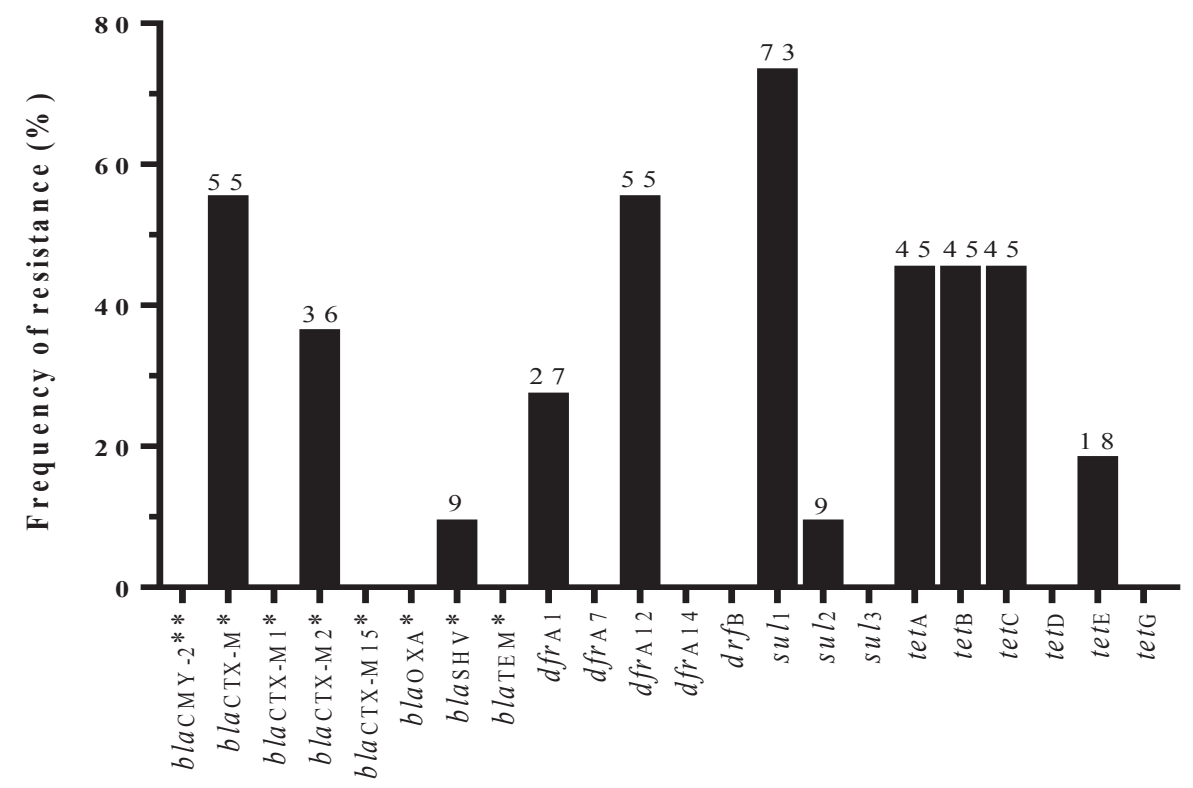

Screened resistance genes

Screened genes: $b l a_{\mathrm{CMY}-2} * * ; b l a_{\mathrm{CTX}-\mathrm{M}} * ; b l a_{\mathrm{CTX}-\mathrm{M} 1} * ; b l a_{\mathrm{CTX}-\mathrm{M} 2} * ; b l a_{\mathrm{CTX}-\mathrm{M} 15} * ; b l a_{\mathrm{OXA}} * ; b l a_{\mathrm{SHV}} * ; b l a_{\mathrm{TEM}} * ; d f r_{\mathrm{A} 1} ; d f r_{\mathrm{A} 7} ; d f r_{\mathrm{Al} 2} ; d f r_{\mathrm{A} 14} ; d r f_{\mathrm{B}}$; $\mathrm{sul}_{1} ; \mathrm{sul}_{2} ;$ sul $_{3} ;$ tet $_{\mathrm{A}} ;$ tet $_{\mathrm{B}} ;$ tet $_{\mathrm{C}} ;$ tet $_{\mathrm{D}} ;$ tet $_{\mathrm{E}} ;$ tet $_{\mathrm{G}}$. $\left.{ }^{* *}\right)$ - gene that also indicate Amp-C production, $(*)$ - gene that also indicate ESBL production. 


\section{Discussion}

Meat is the main protein source in human diet and chicken stands out, because it is the most consumed animal protein worldwide, reaching $13.5 \mathrm{~kg} /$ per capita, with an estimated increase in consumption to $14.1 \mathrm{~kg} /$ per capita in 2026 (OECD/FAO, 2017).

In the world, one in ten people become sick due to FBD (Foodborne Diseases), resulting in 33 million deaths/year and approximately 220 million cases of diarrhea in children under five years. The main etiological FBD agents include Campylobacter spp. and Salmonella spp., which can be present in products of animal origin derived from broilers, cattle, pigs, sheep and ostriches (WHO, 2017).

ESBL producing enterobacteriaceae pose a risk to human health, according to the World Health Organization (WHO, 2014), as in the treatment of infections by enterobacteriaceae in humans, the $\beta$-lactam antibiotics, especially third-generation cephalosporin are the drugs of choice (KOGA et al., 2015).

Studies have shown a high frequency of ESBLproducing bacterial isolates in farm animals and products of animal origin (KOGA et al., 2015; FISCHER et al., 2013; SCHILL et al., 2017). In our study, high levels of resistance were found against the $\beta$-lactam: AMO (100\%); AMP (100\%); monobactams: ATM (72.72\%); first-generation cephalosporin: CFZ (100\%); third-generation: CAZ (45.45\%), CTX (72.72\%), CTF (72.72\%), CRO (72.72\%) and fourth generation: CPM (72.72\%). These isolates also showed resistance to other antimicrobials, such as sulfonamides, tetracycline and trimethoprim, and resistance to three classes of antimicrobials or more characterize features of MDR bacteria (MAGIORAKOS et al., 2012). MDR microorganisms limit therapeutic options, in some cases, cephalosporin are believed to be the latest drugs of choice (JINDAL et al., 2015).

Yaici et al. (2017) noted the risk of transmission of MRD microorganisms to human intestinal microbiota through cross-contamination of foods during processing. The authors found ESBLproducing bacteria in sandwiches sold on the streets in Algeria, indicating cross-contamination, since microorganisms such as E. coli and Salmonella spp. are inactivated after proper hygiene and cooking of food.

In this study, $72.72 \%(08 / 11)$ of the samples were ESBL-producing and 100\% (11/11) MDR to the antimicrobials tested. Ziech et al. (2016) found positivity of $45 \%$ and $86 \%$ for ESBL production and MDR, respectively, in isolates of Salmonella spp. from cutting rooms of slaughterhouses in Brazil and reported on a risk of spreading phenotypes of MDR Salmonella spp. within the broiler industry, corroborated by the findings of this study.

Leverstein-Van Hall et al. (2011) compared the genotypic profile of ESBL in isolates of E. coli and Salmonella spp. of poultry origin with the profile of E. coli isolates from human patients. The authors reported that $19 \%$ of plasmid genes observed in human isolates were indistinguishable from those found in E. coli isolates from poultry origin, reinforcing the hypothesis of risk of transmission along the food chain.

Bacteria can become resistant by acquiring genes from other microorganisms (conjugation, transduction and transformation) of the same or different bacterial species by pressure of selection or mutations (TENOVER, 2006). Poole et al. (2017) demonstrated the capacity that isolates of MDR E. coli have to transfer genetic material via conjugation to receiving strains of $E$. coli $\mathrm{DH} 5 \alpha$ and Salmonella Newport.

ESBL-producing microorganisms may present co-resistance to fluoroquinolones, tetracycline and trimethoprim (SALIU et al., 2017). In this study, $100 \%$ of the isolates were resistant to TET and TRI, which is a concerning fact since these active ingredients are therapeutic options for the treatment of various infections, including urinary tract infection (UTI) in humans. 
The absence of resistance to Chloramphenicol and Nitrofurantoin can be justified by the decrease in pressure of selection after the prohibition of use of these active principles as growth promoters, both in treatment and in animal feed, in accordance with normative instruction No. 9, MAPA (MAPA, 2003). Based on the genotypic resistance profile of isolates of genes that confer resistance, cephalosporin $\left(b l a_{\text {Стхм }}\right)$, tetracycline $\left(\right.$ tet $_{\mathrm{A}}$, tet $_{\mathrm{B}}$ and tet $\left._{\mathrm{C}}\right)$, sulfonamides $\left(s u l_{1}\right)$ and trimethoprim $\left(d f r_{\mathrm{A} 12}\right)$ presented the highest frequencies, corroborating the results of phenotypic resistance profile. The high frequency of resistance to these classes of antimicrobials may be a result of the wide use of these active ingredients in commercial poultry.

Although $100 \%$ of samples presented phenotypic resistance to Ampicillin, no isolate showed genotypic resistance to genes $b l a_{\text {TEM }}$ and $b l a_{\mathrm{OXA}}$ and only $9 \%(1 / 11)$ to $b l a_{\mathrm{SHV}}$ gene, possibly because of the presence of other genes that were not investigated in this study. Studies point to bla ${ }_{\text {CTX-M }}$ $b l a_{\mathrm{SHV}}$ and $b l a_{\mathrm{TEM}}$ as the main genes responsible for ESBL production in bacterial isolates from poultry source (LEVERSTEIN-VAN HALL et al., 2011; SALIU et al., 2017). In this study bla $a_{\text {CTX-M }}$ was the most frequent ESBL gene detected (55\%), followed by $b l a_{\mathrm{CTX}-\mathrm{M} 2}$ and $b l a_{\mathrm{SHV}}$ corroborating with the literature.

\section{Conclusion}

Isolates of Salmonella spp. from poultry products present genotypic and phenotypic characteristics of multiple drug resistance (MDR) and production of extended spectrum of beta lactamase (ESBL).

\section{References}

ABD-ELGHANY, S. M.; SALLAM, K. I.; ABDELKHALEK, A.; TAMURA, T. Occurrence, genetic characterization and antimicrobial resistance of Salmonella isolated from chicken meat and giblets. Epidemiology Infection, Cambridge, v. 143, n. 5, p. $997-$ 1003, 2015. DOI: 10.1017/S0950268814001708
BAUER, A. W.; KIRBY, W. M. M.; SHERRIS, J. C.; TURCK, M. Antibiotic susceptibility testing by standardized single by a standardized single disk method. American Journal of Clinical Pathology, Oxford, v. 45, n. 4, p. 493-496, 1966.

CARATTOLI, A. Plasmids and the spread of resistance. International Journal of Medical Microbiology, Jena, v. 303, p. 298-304, 2013. DOI: 10.1016/j.ijmm.2013.02.001

\section{CLINICAL AND LABORATORY STANDARDS} INSTITUTE - CLSI. M100 - performance standards for antimicrobial susceptibility testing. $27^{\text {th }}$ ed. Wayne: Clinical and Laboratory Standards Institute, 2017. 240 p.

CHEN, S.; ZHAO, S.; WHITE, D. G.; SCHROEDER, C. M.; LU, R.; YANG, H.; MCDERMOTT, P. F.; AYERS, S.; MENG, J. Characterization of multiple-antimicrobialresistant Salmonella serovars isolated from retail meats. Applied and Environmental Microbiology, Washington, v. 70 , n. 1, p. 1-7, 2004. DOI: 10.1128/AEM.70.1.17.2004

DEWEY-MATTIA, D.; MANIKONDA, K.; HALL, A. J.; WISE, M. E.; CROWE, S. J. CDC - Center Diseases Control and prevention, surveillance for foodborne disease outbreaks - United States, 20092015. Surveillance Summaries, Atlanta, v. 67, n. 10, p. 1-11, 2018. Available at: https://www.cdc.gov/mmwr/ volumes/67/ss/ss6710a1.htm. Access at: 18 mar. 2019. DOI: $10.15585 / \mathrm{mmwr.ss} 6710 \mathrm{a} 1$

FISCHER, J.; RODRÍGUEZ, I.; SCHMOGER, S.; FRIESE, A.; ROESLER, U.; HELMUTH, R.; GUERRA, B. Salmonella enterica subsp. enterica producing VIM-1 carbapenemase isolated from livestock farms. Journal of Antimicrobial Chemotherapy, London, v. 68, n. 2, p. 478480, 2013. DOI: 10.1093/jac/dks393

GALLARDO, F.; RUIZ, J.; MARCO, F.; TOWNER, K. J.; VILA, J. Increase of incidence of resistance to ampicillin, chloramphenicol and trimethoprim in clinical isolates of Salmonella serotype Typhimurium with investigation of molecular epidemiology and mechanisms of resistance. Journal of Medical Microbiology, London, v. 48, n. 4, p. 367-374, 1999. DOI: 10.1099/00222615-48-4-367

JINDAL, B. A. K.; PANDYA, M. K.; KHAN, M. I. D. Antimicrobial resistance: a public health challenge. Medical Journal Armed Forces India, New Delhi, v. 71, n. 2, p. 178-181, 2015. DOI: 10.1016/j.mjafi.2014.04.011

KOGA, V. L.; SCANDORIEIRO, S.; VESPERO, E. C.; OBA, A.; BRITO, B. G. de; BRITO, K. C. de; NAKAZATO, G.; KOBAYASHI, R. K. Comparison of antibiotic resistance and virulence factors among Escherichia coli isolated from conventional and freerange poultry. BioMed Research International, New York, v. 2015, p. 1-8, 2015. DOI: /10.1155/2015/618752 
LAHEY CLINIC. B-Lactamase classification and amino acid sequences for TEM, SHV and OXA extendedspectrum and inhibitor resistant enzymes. Burlington, 2017. Available at: https://www.lahey.org/ studies. Access at: 12 sept. 2017.

LEVERSTEIN-VAN HALL, M. A.; DIERIKX, C. M.; COHEN STUART, J.; VOETS, G. M.; VAN DEN MUNCKHOF, M. P.; VAN ESSEN-ZANDBERGEN, A.; PLATTEEL, T.; FLUIT, A. C.; VAN DE SANDEBRUINSMA, N.; SCHARINGA, J.; BONTEN, M. J. M.; MEVIUS, D. J. Dutch patients, retail chicken meat and poultry share the same ESBL genes, plasmids and strains. Clinical Microbiology and Infection, London, v. 17 , n. 6 , p. $873-880,2011$. DOI: $10.1111 /$ j.14690691.2011.03497.x

MA, M.; WANG, H.; YU, Y.; ZHANG, D.; LIU, S. Detection of antimicrobial resistance genes of pathogenic Salmonella from swine with DNA microarray. Journal of Veterinary Diagnostic Investigation, Thousand Oaks, v. 19, n. 2, p. 161-167, 2007. DOI: $10.1177 / 104063870701900204$

MAGIORAKOS, A. P.; SRINIVASAN, A.; CAREY, R. B.; CARMELI, Y.; FALAGAS, M. E.; GISKE, C. G.; HARBARTH, S.; HINDLER, J. F.; KAHLMETER, G.; OLSSON-LILJEQUIST, B.; PATERSON, D. L.; RICE, L. B.; STELLING, J.; STRUELENS, M. J; VATOPOULOS, A.; WEBER, J. T.; MONNET, D. L. Multidrug-resistant, extensively drug-resistant and pandrug-resistant bacteria: an international expert proposal for interim standard definitions for acquired resistance. Clinical Microbiology and Infection, London, v. 18, n. 3, p. 268-281, 2012. DOI: 10.1111/j.1469-0691.2011.03570.x

MINISTÉRIO DA AGRICULTURA PECUÁRIA E ABASTECIMENTO - MAPA. Instrução Normativa, $n^{\circ}$. 8, 23 de janeiro de 1995. Método analítico de carcaça de aves e pesquisa de Salmonella. Brasília, 1995. Disponível em: https://www.defesa.agricultura.sp.gov. br/legislacoes/portaria-sda-8-de-23-01-1995,376.html. Acesso em: 24 mar. 2019.

MINISTÉRIO DA AGRICULTURA PECUÁRIA E ABASTECIMENTO - MAPA. Instrução Normativa, $n^{\circ} .9$, 27 de junho de 2003. Proíbe a fabricação, a manipulação, o fracionamento, a comercialização, a importação e o uso dos princípios ativos cloranfenicol nitrofuranos e os produtos que contenham estes princípios ativos, para uso veterinário e suscetível de emprego na alimentação de todos os animais e insetos. Brasília, 2003. Disponível em: http://sistemasweb.agricultura.gov.br/sislegis/ action/detalhaAto. do?method=visualizarAtoPortalMapa $\&$ chave $=2112258128$. Acesso em: 15 set. 2017.
MINISTÉRIO DA AGRICULTURA PECUÁRIA E ABASTECIMENTO - MAPA. Instrução Normativa, $n^{\circ}$. 26, 09 de julho de 2009 (Portaria ${ }^{\circ}$ 193/1998). Regulamento técnico para a fabricação, o controle de qualidade, a comercialização e o emprego de produtos Antimicrobianos de uso veterinário. Brasília, 2009. Disponível em: http://www.agricultura.gov.br/assuntos/ insumos-agropecuarios/insumos-pecuarios/ alimentacao -animal/arquivos-alimentacao-animal/legislacao/ instrucao-normativa-no-26-de-9-de-julho-de-2009.pdf. Acesso em: 19 mar. 2019.

MELENDEZ, S. N.; HANNING, I.; HAN, J.; NAYAK, R.; CLEMENT, A. R.; WOOMING, A.; HERERRA, P.; JONES, F. T.; FOLEY, S. L.; RICKE, S. C. Salmonella enterica isolates from pasture-raised poultry exhibit antimicrobial resistance and class I integrons. Journal of Applied Microbiology, Oxford, v. 109, n. 6, p. 19571966, 2010. DOI: 10.1111/j.1365-2672.2010.04825.x

MILLAN, A. S. Evolution of plasmid-mediated antibiotic resistance in the clinical context. Trends in Microbiology, Cambridge, v. 26, n. 12, p. 978-985, 2018. DOI: $10.1016 / j . t i m .2018 .06 .007$

NAVIA, M. M.; RUIZ, J.; SANCHEZ-CESPEDES, J.; VILA, J. Detection of dihydrofolate reductase genes by PCR and RFLP. Diagnostic Microbiology and Infectious Disease, New York, v. 46, n. 4, p. 295-298, 2003. DOI: 10.1016/S0732-8893(03)00062-2

ORGANIZATION FOR ECONOMIC CO-OPERATION AND DEVELOPMENT/FOOD AND AGRICULTURE ORGANIZATION - OECD/FAO. OECD-FAO Agricultural Outlook, OECD Agriculture statistics (database). Paris, Rome, 2017. Available at: http://dx.doi. org/10.1787/ 888933522586. Access at: 14 sept. 2017.

PITOUT, J. D. D.; NORDMANN, P.; LAUPLAND, K. B.; POIREL, L. Emergence of Enterobacteriaceae producing extended-spectrum b-lactamases (ESBLs) in the community. Journal of Antimicrobial Chemotherapy, London, v. 56, n. 1, p. 52-59, 2005. DOI: 10.1093/jac/ dki166

POOLE, T. L.; CALLAWAY, T. R.; NORMAN, K. N.; SCOTT, H. M.; LONERAGAN, G. H.; ISON, S. A.; BEIER, R. C.; HARHAY, D. M.; NORBYF, B.; NISBET, D. J. Transferability of antimicrobial resistance from multidrug-resistant Escherichia coli isolated from cattle in the USA to E. coli and Salmonella Newport recipientes. Journal of Global Antimicrobial Resistance, Amsterdam, v. 11, p. 123-132, 2017. DOI: 10.1016/j. jgar.2017.08.001

RAWAT, D.; NAIR, D. Extended-spectrum $\beta$-lactamases in Gram Negative bacteria. Journal of Global Infectious 
Diseases, Mumbai, v. 2, n. 3, p. 263-274, 2010. DOI: 10.4103/0974-777X.68531

SALIU, E. M.; VAHJEN, W.; ZENTEK, J. Types and prevalence of extended-spectrum beta-lactamase producing Enterobacteriaceae in poultry. Animal Health Research Reviews, Wallingford, v. 18, n. 1, p. 46-57, 2017. DOI: $10.1017 / \mathrm{S} 1466252317000020$

SCHILL, F.; ABDULMAWJOOD, A.; KLEIN, G.; REICH, F. Prevalence and characterization of extendedspectrum $\beta$-lactamase (ESBL) and AmpC $\beta$-lactamase producing Enterobacteriaceae in fresh pork meat at processing level in Germany. International Journal of Food Microbiology, Amsterdam, v. 257, p. 58-66, 2017. DOI: $10.1016 / j$.jjfoodmicro.2017.06.010

SILVA, K. C. Monitoramento dos mecanismos de resistência em Salmonella e Escherichia coli isoladas de animais de produção agropecuária e alimentos derivados. 2011. Dissertação (Mestrado em Microbiologia) - Universidade de São Paulo Instituto de Ciências Biomédicas, São Paulo.

TENOVER, F. C. Mechanisms of antimicrobial resistance in bacteria. The American Journal of Medicine, New York, v. 119, n. 6, p. S3-S10, 2006. DOI: 10.1016/j. amjmed.2006.03.011

WANG, H.; YE, K.; WEI, X.; CAO, J.; XU, X.; ZHOU, G. Occurrence, antimicrobial resistance and biofilm formation of Salmonella isolates from a chicken slaughter plant in China. Food Control, Kidlington, v. 33, n. 2, p. 378-384, 2013. DOI: 10.1016/j.foodcont.2013.03.030
WORLD HEALTH ORGANIZATION - WHO. Antimicrobial resistance: global report on surveillance. Geneva: WHO Press., 2014. Available at: http://www. who.int/drugresistance/documents/ surveillancereport. Access at: 14 sept. 2017.

WORLD HEALTH ORGANIZATION - WHO. Media Centre/Campylobacter. Geneva, 2017. Available at: http://www.who.int/mediacentre/factsheets/fs255/en/. Access at: 5 out. 2017.

YAICI, L.; HAENNI, M.; MÉTAYER, V.; SARAS, E.; ZEKAR, F. M.; TOUATI, A.; MADEC, J. Spread of ESBL/AmpC-producing Escherichia coli and Klebsiella pneumoniae in the community through ready-to-eat sandwiches in Algeria. International Journal of Food Microbiology, Amsterdam, v. 245, p. 66-72, 2017. DOI: 10.1016/j.ijfoodmicro.2017.01.011

ZIECH, R. E.; LAMPUGNANI, C.; PERIN, A. P.; SERENO, M. J.; SFACIOTTE, R. A. P.; VIANA, C.; SOARES, V. M.; PINTO, J. P. A. N.; BERSOT, L. S. Multidrug resistance and ESBL-producing Salmonella spp. isolated from broiler processing plants. Brazilian Journal of Microbiology, Rio de Janeiro, v. 47, n. 1, p. 191-195, 2016. DOI: 10.1016/j.bjm.2015.11.021

ZISHIRI, O. T.; MKHIZE, N.; MUKARATIRWA, S. Prevalence of virulence and antimicrobial resistance genes in Salmonella spp. isolated from commercial chickens and human clinical isolates from South Africa and Brazil. Onderstepoort Journal of Veterinary Research, Pretoria, v. 83 , n. 1, p. 1-11, 2016. DOI: 10.4102/ojvr.v83i1.1067 